\title{
PENGARUH PENAMBAHAN ADITIF CAIR BUAH NAGA MERAH DAN AIR KELAPA TERHADAP KECERNAAN PROTEIN KASAR, ENERGI METABOLIS DAN PRODUKTIVITAS BURUNG PUYUH
}

(The influence of liquid additive addition of red dragon fruit and coconut water on the digestibility of energy and crude protein for productivity quail)

\section{Uki D, Fajar Wahyono, Bambang Sukamto}

\author{
Program Studi S-1 Peternakan Fakultas Peternakan dan Pertanian, \\ Universitas Diponegoro, Semarang \\ udestiawan@gmail.com
}

\begin{abstract}
ABSTRAK
Penelitian ini bertujuan untuk mengkaji dan mengetahui pengaruh pemberian aditif cair buah naga merah dan air kelapa terhadap kecernaan protein kasar dan energimetabolis, produktifitas burung puyuh. penelitian menggunakan puyuh betina sebanyak 120 ekor umur 20 minggu. Kandang menggunakan kandang battery. Aditif cair yang diberikan adalah buah naga merah dan air kelapa. Rancangan percobaan yang digunakan adalah Rancangan Acak Lengkap dengan 5 perlakuan dan 4 ulangan. Perlakuan digunakan adalah $\mathrm{T} 0=$ tanpa perlakuan , $\mathrm{T} 1=$ aditif cair buah naga merah $50 \mathrm{ml} 2 \mathrm{x}$ sehari, $\mathrm{T} 2=$ aditif cair air kelapa $50 \mathrm{ml} 2 \mathrm{x}$ sehari, $\mathrm{T} 3$ = aditif cair buah naga merah $50 \mathrm{ml} 1 \mathrm{x}$ pagi hari dan air kelapa $50 \mathrm{ml}$ 1x siang hari, T4 = aditif cair buah naga merah dan air kelapa yang dicampur $50 \mathrm{ml}$ 2x sehari. Parameter yang diamati adalah konsumsi pakan, kecernaan protein kasar dan energi, quail day production, dan konversi pakan. Hasil penelitian menunjukkan pengaruh pemberian aditif cair buah naga merah dan air kelapa berpengaruh nyata $(\mathrm{P}>0,05)$ terhadap quail day production, tetapi tidak memberikan pengaruh nyata $(\mathrm{P}<0,05)$ terhadapkonsumsi, konversi pakan, kecernaan protein dan energi energy metabolis.
\end{abstract}

Kata Kunci : burung puyuh, aditif cair, kecernaan.

\section{ABSTRACT}

This study aims to assess and influence the administration of a liquid additive red dragon fruit and coconut water on the digestibility of metabolism energy and crude protein for productivity quail. This research using a total of 120 female quail age of 20 weeks. Enclosure using battery cages. Liquid additive that is given is the red dragon fruit and coconut water. The experimental design used was completely randomized design with 5 treatments and 4 repetitions. The treatment used is $T O=$ without treatment, $T 1=$ liquid additive red dragon fruit $50 \mathrm{ml} 2 x$ per day, T2 = liquid additive coconut water $50 \mathrm{ml} 2 x$ per day, $T 3$ = liquid additive red dragon fruit $50 \mathrm{ml} 1 \mathrm{x}$ in the morning and coconut water $50 \mathrm{ml} 1 \mathrm{x}$ in the day, $\mathrm{T4}=$ liquid additive red dragon fruit and coconut water mixed with 50 $\mathrm{ml} 2 \mathrm{x}$ per day. The observed parameters were feed intake, digestibility of crude protein and metabolism energy, quail day production, and feed conversion. The results show the influence liquid additives Award red dragon fruit and coconut water is significant 
$(P>0.05)$ on quail day production, but no significant effect $(P<0.05)$ on feed conversion, digestibility of protein and metabolism energy.

Keywords: quail, a liquid additive, digestibility.

\section{PENDAHULUAN}

Burung puyuh merupakan salah satu ternak unggas yang berpotensi dibudidayakan, karena produksi telurnya mencapai $80 \%$. Burung puyuh yang sudah afkir juga dapat dimanfaatkan dagingnya untuk memenuhi kebutuhan daging dipasar. Pemeliharaan burung puyuh membutuhkan modal yang relative kecil dibandingkan dengan unggas lainnya. Untuk menunjang produktivitas yang tinggi, peternak selalu memberikan aditif buatan dalam ransum maupun air minum. Salah satu alternatif pengganti aditif buatan tersebut dengan aditif alami berupa buah naga merah (Hylocereus polyrhizus) dan air kelapa. Buah naga dan air kelapa dimanfaatkan sebagai aditif nutritive dan bersifat organik bagi burung puyuh karena lebih mudah untuk diaplikasikan, lebih aman dan tidak meninggalkan residu dalam produk ternak.

Buah naga secara umum mengandung vitamin B (B1, B2 dan B3) dan vitamin C. Vitamin B1 (thiamin) berfungsi untuk menghasilkan energi Vitamin B2 (riboflavin) memiliki fungsi untuk pertumbuhan dan perbaikan jaringan yang rusak. Vitamin $\mathrm{C}$ yang berfungsi menurunkan $\mathrm{pH}$ saluran pencernaan sehingga meningkatkan kecernaan burung puyuh. Antioksidan dibutuhkan untuk menangkal radikal bebas dan menghambat terjadinya reaksi berantai dari pembentukan radikal bebas yang dapat menimbulkan stress oksidatif.

Air kelapa merupakan salah satu produk dari tanaman kelapa yang belum banyak dimanfaatkan dan merupakan salah satu limbah dari buah kelapa. Air Kelapa juga mengandung vitamin C 2,7 mg/ 100 ml. Air kelapa juga memiliki kandungan mineral dan sukrosa yang sempurna sehingga memiliki keseimbangan elektrolit yang berguna untuk meminimalisir maupun mengembalikan stamina tubuh dari cekaman panas atau perubahan cuaca yang ekstrim yang berakibatkan stress sehingga dapat mengalami penurunan produksi..

Penelitian ini bertujuan untuk mengkaji dan mengetahui pengaruh pemberian aditif cair buah naga merah dan air kelapa terhadap kecernaan protein kasar, energimetabolisdan produktifitas burung puyuh. Manfaat dari penelitian ini adalah dapat memberikan informasi kepada peternak untuk mengetahui pengaruh pemberian aditif cair buah naga merah (Hylocereus polirhyzus) dan air kelapa sebagai pada perlakuan yang berbeda terhadap kecernaan dan performan produksi telur burung puyuh. Hipotesis dari penelitian ini adalah pemberian aditif cair buah naga merah dan air kelapa sebagai tambahan air minum dapat memperbaiki kecernaan, energy metabolisdan performa produksi telur burung puyuh (Coturnix coturnix japonica).

\section{MATERI DAN METODE}

Materi yang digunakan dalam penelitian ini adalah puyuh betina sebanyak 120 ekor umur 20 minggu (120 hari) dengan BB 13,61 $\pm 0,49$ g yang diperoleh dari Salma Poultry Shop di Kecamatan Suruh Kabupaten Semarang. Ransum yang digunakan tersusun dari beberapa bahan 
pakan yang digunakan terdiri dari bekatul, jagung kuning, konsentrat, tepung ikan, bungkil kedelai dan top mix. Ransum tersusun berdasarkan kandungan energi metabolis $\pm 3000 \mathrm{kkal} / \mathrm{kg}$ dan protein kasar $\pm 20 \%$. Aditif cair yang diberikan adalah buah naga merah (Hylocereus polyrhizus) dan air kelapa.

Berdasarkan penelitian ini perngaruh penambahan aditif cair buah naga merah dan air kelapa terhadap kecernaan protein kasar dan energimetabolis, produktivitas burung puyuh. Rancangan percobaan yang digunakan adalah Rancangan Acak Lengkap (RAL) dengan 5 perlakuan 4 ulangan dan 6 ekor itik untuk setiap unit percobaan. Perlakuan yang diberikan yakni : $\mathrm{T}_{0}$ : tanpa pemberian aditif cair buah naga merah (tanpa perlakuan). $\mathrm{T}_{1}$ : pemberian aditif cair buah naga merah sebanyak $50 \mathrm{ml}$ sehari 2x (pagi pukul 10.00 dan siang pukul 14.00). $\mathrm{T}_{2}$ : pemberian aditif cair air kelapa sebanyak $50 \mathrm{ml}$ sehari 2x (pagi pukul 10.00 dan siang pukul 14.00). $\mathrm{T}_{3}$ : Pemberian aditif cair buah naga merah sebanyak $50 \mathrm{ml}$ 1x (pagi pukul 10.00) dan pemberian aditif cair air kelapa $50 \mathrm{ml} \mathrm{1x}$ (siang pukul 14.00). $T_{4}$ : pemberian aditif cair buah naga merah dan air kelapa yang dicampur dengan perbandingan 50:50 sebanyak $50 \mathrm{ml}$ 2x (pagi pukul 10.00 dan siang pukul 14.00). Penelitian dilakukan dalam beberapa tahap, yang meliputi tahap persiapan, tahap penerapan perlakuan, tahap pengumpulan data serta analisis data hasil penelitian dan tahap pembuatan laporan.

Tahap perisapan penelitian dilakukan selama 1 minggu di Kandang Non Ruminansia Fakultas Peternakan dan Pertanian Universitas Diponegoro Semarang. Kegiatan yang dilaksanakan dalam tahap persiapan adalah mempersiapkan kandang serta tempat pakan dan tempat minum, mempersiapkan pakan, mempersiapkan puyuh umur 4 bulan, mempersiapkan aditif cair buah naga merah dan air kelapa, memasang lampu sebagai penerangan dan mempersiapkan alat-alat pendukung yang akan digunakan dalam penelitian. Persiapan kandang dilakukan dengan membersihkan kandang, melakukan pengapuran dan fumigasi kandang. Persiapan dan pembuatan aditif cair buah naga merah dilakukan dengan mencari buah naga merah dan air kelapa terlebih dahulu di pasar Banyumanik, kemudian membuat aditif cair buah naga merah dengan perbandingan antara buah naga dan air adalah 1 : 5, yang artinya setiap 100 gram buah naga merah ditambah air sebanyak $500 \mathrm{ml}$ air, kemudian dihaluskan dan dimasukkan ke dalam kulkas dan untuk air kelapa hanya penyimpanannya didalam kulkas supaya tidak cepat busuk.. Tahap perlakuan dilakukan selama 3 minggu yang dimulai pada umur 4 bulan sampai umur 5 bulan.

Tahap perlakuan dilakukan selama 3 minggu yang dimulai pada umur 4 bulan sampai umur 5 bulan. Tahap perlakuan dimulai dengan penimbangan bobot badan awal burung puyuh yang sebelumnya telah dilakukan adaptasi pemberian pakan. Setelah memasuki tahap perlakuan, burung puyuh diberikan perlakuan dengan pemberian aditif cair buah naga merah dan air kelapa sebagai tambahan air minum. Aditif cair buah naga dan air kelapa diberikan sebanyak $50 \mathrm{ml}$ setiap petak kandang dengan dosis pemberian sebanyak $8,3 \mathrm{ml}$ per ekor. Pemberian aditif cair buah naga merah diberikan pada perlakuan $\mathrm{T} 1$, pemberian aditif cair air kelapa diberikan pada perlakuan $\mathrm{T} 2$, pemberian aditif cair buah naga dipagi hari dan aditif cair air kelapa di siang hari diberikan pada perlakuan T3 dan pemberian campuran 
aditif cair buah naga merah dan air kelapa perbandingan 1:1 diberikan pada perlakuan T4, semua perlakuan diberikan pada pagi hari pukul 10.00 WIB dan siang pada pukul 14.00 WIB . Ransum diberikan sesuai standar pemberian ransum, sedangkan air minum diberikan secara ad libitum.. Pengukuran suhu dan kelembaban dilakukan pada pagi hari, siang hari dan sore hari. Data yang diambil meliputi : mencatat dan menghitung konsumsi pakan setiap hari, menghitung konversi, menghitung kecernaan protein kasar dan energi metabolisme yang dilakukan dengan metode total koleksi selama 3 hari berturutturut, serta menghitung produktivitas telur setiap hari pada fase layer.

Tabel 1. Kandungan Nutrisi Bahan Penyusun Ransum

\begin{tabular}{lccccc}
\hline \hline \multicolumn{1}{c}{ BahanPakan } & EM & PK & LK & SK & Abu \\
\hline JagungKuning & $---\mathrm{kkal} / \mathrm{kg}---$ & & $----------\%^{-}$ & ---------- & \\
Bekatul & $3.343,50$ & 8,90 & 0,95 & 0,11 & 1,49 \\
Bungkilkedelai & $2.286,70$ & 9,50 & 5,20 & 15,86 & 7,70 \\
Konsentrat CP 124 & $3.341,70$ & 44,62 & 1,11 & 4,40 & 5,80 \\
Tepungikan & $2.755,60$ & 30,50 & 3,51 & 7,50 & 20,02 \\
\hline Ken & $3.434,80$ & 41,49 & 0,20 & 0,30 & 8,20 \\
\hline
\end{tabular}

Keterangan : Hasil analisisis proksimat laboratorium balai pengkajian teknologi pertanian Jawa Tengah, Ungaran (2015).

Tabel 2. Komposisi Ransum dan Kandungan Nutrisi Ransum Penelitian.

\begin{tabular}{lc}
\hline \hline Komposisi bahan pakan & Ransum layer \\
\hline Jagung kuning & 48,00 \\
Bekatul & 8,00 \\
Bungkil kedelai & 6,00 \\
Konsentrat CP 124 & 30,00 \\
Tepung ikan & 7,00 \\
Premix & 1,00 \\
\hline Total & $\mathbf{1 0 0}$ \\
\hline Kandungan Nutrisi Ransum & \\
\hline Protein Kasar $(\%)$ & 19,76 \\
Energi Metabolis (kkal/kg)** & 3012 \\
Serat Kasar $(\%)^{*}$ & 3,86 \\
Lemak Kasar $(\%)^{*}$ & 2,00 \\
Abu $(\%) *$ & 8,25 \\
Kadar kalsium $(\%)^{* *}$ & 3,63 \\
Kadar fosfor $(\%)^{* *}$ & 1,95 \\
\hline Keterangan &
\end{tabular}

Keterangan :

(*) Hasil analisis proksimat Laboratorium Balai Pengkajian Teknologi Pertanian Jawa Tengah, Ungaran (2015).

(**) Hasil analisis Laboratorium Ilmu Nutrisi dan Pakan, Fakultas Peternakan dan Pertanian, Universitas Diponegoro (2015). 


\section{HASIL DAN PEMBAHASAN}

Hasil penelitian perbandingan penambahan aditif cair buah naga dan air kelapa terhadap kecernaan protein kasar, energy dan produktivitas burung puyuh disajikan pada Tabel 3.

Tabel 3. Rata-rata nilai konsumsi ransum, KcPK, EM, Quail day production, dan konversi ransum pada penambahan aditif cair buah naga merah dan air kelapa pada burung puyuh.

\begin{tabular}{cccccc}
\hline \hline Parameter & T0 & T1 & T2 & T3 & T4 \\
\hline Konsumsi Ransum & 21.47 & 21.87 & 21.80 & 21.90 & 21.82 \\
KcPK & 76.08 & 72.89 & 72.33 & 73.01 & 72.13 \\
Energi Metabolisme & 2832.58 & 2491.28 & 2595.30 & 2643.53 & 2474.52 \\
Quail Day Production & $61.84^{\mathrm{b}}$ & $67.66^{\mathrm{b}}$ & $81.74^{\mathrm{a}}$ & $70.24^{\mathrm{ab}}$ & $72.65^{\mathrm{ab}}$ \\
Konversi Pakan & 2.10 & 2.11 & 2.16 & 2.18 & 2.18 \\
\hline
\end{tabular}

Keterangan: nilai rata-rata pada konsumsi ransum, KcPK, EM, dan Konversi Pakan menunjukkan perbedaan tidak nyata $(\mathrm{P}>0,05)$, sedangkan nilai Quail Day Pruduction mengalami perbedaan nyata $(\mathrm{P}<0,05)$.

\section{Pengaruh Perlakuan terhadap Konsumsi Ransum}

Berdasarkan hasil penelitian perbandingan penambahan aditif cair buah naga merah (Hylocereus polyrhizus) dan air kelapa tua terhadap konsumsi ransum disajikan pada Tabel 3. Berdasarkan hasil analisis ragam, penambahan aditif cair buah naga merah (Hylocereus polyrhizus) dan air kelapa tua berpengaruh nyata $(\mathrm{P}>0,05)$ terhadap konsumsi ransum. Rata-rata konsumsi ransum burung puyuh pada tabel 3, T0, T1, T2, T3, dan T4 masing-masing sebesar 21,47; 21,87; 21,80, 21,90 dan 21,82 g/ekor/hari. Konsumsi ransum tersebut masih berada pada kisaran normal. Hal ini sesuai dengan pendapat Zahra et al. (2012) bahwa konsumsi pakan burung puyuh lebih dari 6 minggu sebanyak 21 g/ekor/hari. Subekti (2009) menyatakan bahwa penambahan aditif vitamin $\mathrm{C}$ pada ransum dapat mengurangi cekaman panas pada ternak sehingga konsumsi ransum tidak tergangguHal ini dikarenakan pemberianzataditifcairbuahnagadn air kelapa 8,3ml per ekorpadaperlakuan $\mathrm{T} 1$,
T2, T3 dan T4 dengankonsentrasi vitamin C $0,10,0,37,0,47$ dan $0,47 \%$ masih sedikit dankurangsehingga asupan vitamin tidak berpengaruh pada cekaman panas. Hal inisesuaidenganpendapatAstutiet al. (2015), bahwapemberianaditifdengandosis yang masihsedikitbelummampumemberikanpeng aruh yang signifikan

\section{Pengaruh Perlakuan terhadap KcPK}

Berdasarkan hasil penelitian perbandingan penambahan aditif cair buah naga merah (Hylocereus polyrhizus) dan air kelapa tua terhadap kecernaan protein kasar. Berdasarkan hasil analisis ragam, penambahan aditif cair buah naga merah (Hylocereus polyrhizus) dan air kelapa tuatidak berpengaruh nyata $(\mathrm{P}>0,05)$ terhadap kecernaan protein kasar (KcPK)..

Rata-rata kecernaan protein kasar (KcPK) burung puyuh pada tabel 3, T0, T1, T2, T3 dan T4 masing-masing sebesar 76,$08 ; 72,89 ; 72,33 ; 73,01$ dan 72,13\%. Kecernaan protein kasar (KcPK) tersebut masih pada kisaran normal. Hal ini sesuai dengan pendapat Tillman et al., (1991) 
yang menyatakan bahwa kualitas daya cerna ransum diatas $65 \%$ tergolong kualitas tinggi. Menurut Wahju (2004) bahwa protein kasar bahan pakan penyusun ransum unggas memiliki kecernaan antara 67-80\%.Vitamin C bersifat acidifier dapat menurunkan $\mathrm{pH}$ saluran pencernaan, mekanisme kerja acidifier adalah memperbaiki kecernaan dengan meningkatkan aktivitas enzim, penurunan pH lambung.Hal ini sesuai dengan pendapat Yuliansyahet al. (2015) menyatakan bahwa vitamin $\mathrm{C}$ dapatmenurunkan $\mathrm{pH}$ saluran pencernaan. Hal ini dikarenakan pemberian zat aditif cair uahnagadn air kelapa $8,3 \mathrm{ml}$ per ekorpadaperlakuan T1, T2, T3 dan T4 dengan konsentrasi vitamin C 0,10, 0,37, 0,47 dan $0,47 \%$ masih sedikit sehingga asupan vitamin belum dapat menurunkan $\mathrm{pH}$ saluran pencernaan burung puyuh. MenurutAtapattu danNelligaswatta (2005), pemberianasamsitrat organic level $2 \%$ padaayam broiler secaranyata $(\mathrm{P}<0,05)$ dapat meningkatkan nilai kecernaan serat kasar dan protein kasar.

\section{Pengaruh Perlakuan terhadap Energi Metabolisme}

Berdasarkan hasil penelitian perbandingan penambahan aditif cair buah naga merah (Hylocereus polyrhizus) dan air kelapa terhadap kecernaan energi metabolis disajikan pada Tabel 3. Berdasarkan hasil analisis ragam, pemberian aditif cair buah naga merah (Hylocereus polyrhizus) tidak berpengaruh nyata $(\mathrm{P}>0,05)$ terhadap kecernaan energi metabolis.

Rata-rata kecernaan energi metabolis untuk masing-masing perlakuan T0, T1, T2, T3 dan T4 sebesar 2832,58 2491,28; 2595,$30 ; 2643,53$ dan 2474,52 Kkal/kg. Hasil energi metabolis tersebut lebih rendah dari hasil penelitian Dianti (2012) bahwa rata-rata energi metabolis burung puyuh dengan pemberian C. usaramoensis dalam ransum memiliki hasil sebesar 3079,713319,77 Kkal/kg.Tingkat kecernaan energi metabolisme (EM) burung puyuh.Menurut Wahju (2004) bahwa tingkat energi di dalam ransum menentukan banyaknya ransum yang dikonsumsi, sedangkan jumlah konsumsi ransum dipengaruhi oleh temperatur lingkungan, imbangan nutrisi ransum, kesehatan dan bobot badan

\section{Pengaruh Perlakuan terhadap Quail Day Production}

Berdasarkan hasil penelitian perbandingan pemberian aditif cair buah naga merah (Hylocereus polyrhizus) dan air kelapa terhadap Quail Day Production (QDP) disajikan pada Tabel 3. Berdasarkan hasil analisis ragam, penambahan aditif cair buah naga merah (Hylocereus polyrhizus) dan air kelapaberpengaruh nyata $(\mathrm{P}<0,05)$ terhadap Quail Day Production (QDP).

Rata-rata persentase Quail Day Production (QDP) yang diperoleh selama penelitian untuk masing-masing perlakuan T0, T1, T2, T3 dan T4 sebesar 61,84;67,66; 81,$74 ; 70,24 ; 72,65 \%$. Menurut Triyanto (2007) bahwa pemberian pakan dengan kandungan energi $2700 \mathrm{Kkal} / \mathrm{kg}$ cukup untuk produksi telur optimum yaitu 79,09\% pada umur 9-19 minggu dengan konversi pakan 3,43. Tingkat Quail Day Production (QDP).Hal ini disebabkan adanya kandungan mineral kalsium, fosfor dan besi pada air kelapa yang tinggi. Mineral diperlukan untuk kehidupan puyuh, khususnya $\mathrm{Ca}$ dan $\mathrm{P}$ sangat berperan pada pembentukan kulit telur puyuh (Rasyaf, 1984).Hal inisesuaidenganPanjuaningrum (2009) bahwa air kelapamengandung mineral diantaranyakalsium, fosfor, danbesi yang bermanfaat untuk meningkatkan kualitas telur unggas. 


\section{Pengaruh perlakuan terhadap Konversi Ransum}

Berdasarkan hasil penelitian penambahan aditif cair buah naga merah (Hylocereus polyrhizus) dan air kelapa terhadap konversi ransum disajikan pada Tabel 3. Berdasarkan hasil analisis ragam, penambahan aditif cair buah naga merah (Hylocereus polyrhizus) dan air kelapa tuatidak berpengaruh nyata $(\mathrm{P}>0,05)$ terhadap konversi ransum.

Rata-rata konversi ransum yang diperoleh selama penelitian untuk masingmasing perlakuan T0, T1, T2, T3 dan T4 sebesar 2,10;2,11;2,16;2,18 dan 2,18. Nilai konversi ransum yang diperoleh masih dibawah standar. Menurut Kartasudjana dan Nayoan (1997) bahwa nilai konversi pakan burung puyuh yang baik berkisar antara 2,70-2,80.

\section{KESIMPULAN}

Berdasarkan hasil penelitian menunjukkan bahwa pengaruh penambahan aditif cair buah naga merah dan air kelapa pada perlakuan $\mathrm{T} 1$ dengan buah naga merah sebanyak 50ml 2x sehari, T2 dengan air kelapa sebanyak 50ml 2x sehari, T3 dengan buah naga merah sebanyak $50 \mathrm{ml} 1 \mathrm{x}$ dipagi hari dan air kelapa tua sebanyak $50 \mathrm{ml} 1 \mathrm{x}$ disiang hari dan T4 dengan campuran buah naga merah dan air kelapa sebanyak $50 \mathrm{ml}$ $2 \mathrm{x}$ sehari meningkatkan quail day production (QDP), tetapi tidak meningkatkan konsumsi pakan, kecernaan protein kasar (KcPK), kecernaan energi metabolis dan konversi pakan.

\section{DAFTAR PUSTAKA}

Astuti T, P. Juandes, G. Yelni, and Y. S. Amir. 2015. The effect of a local biothechnological approach on rumen fluit characteristics $(\mathrm{pH}$, $\mathrm{NH}_{3}, \mathrm{VFA}$ ) of the oil palm fronds as ruminant feed. Internasional Journal of Agriculture innovations and research Volume 3, Issue 6, ISSN(Online) 2319-1473.

Atapattu, N.S.B.M and C.J. Nelligaswatta. 2005. Effects of critic acid on the performance and the utilization of phosphorous and crude protein in broiler chickens fedd on rice by products based diets. Int. J. of Poult. Sci. 4 (12): 990-993.

Dianti, R. Mulyono, F. Dan Wahyono, 2012. Pemberian daun Crostalaria usaramoensis sebagai sumber protein ransum burung puyuh periode grower terhadap energi metabolis, retensi nitrogen dan efisiensi ransum. Animal Agricultural Juounal. 1 (1):203-214

Kartasudjana, R., dan Nayoan, M. 1997. Pengaruh limbah ikan cakalang dalam ransum terhadap performans puyuh petelur. J. Pengembangan Peternakan Tropis. 22 (4): 12-18.

Listiyowati, E. dan K. Roospitasari, 2005. Tatalaksana Budidaya Puyuh Secara Komersial. Edisi Revisi. Penebar Swadaya, Jakarta.Dahuri, R. 2004. Pengelolaan Sumber Daya Wilayah Pesisir dan Lautan Secara Terpadu, Edisi Revisi. Pradnya Paramita.

Jakarta.

Panjuantiningrum, S. 2009. Pengaruh Pemberian Buah Naga Merah (Hylocereus polyrhizus) terhadap Kadar Glukosa Darah Tikus Putih yang Diinduksi Aloksan. Fakultas Kedokteran Universitas Sebelas Maret, Surakarta. (Skripsi).Irwan. 2003. Menggali Manfaat Rumput Laut. Riset Unggulan ITB. Bandung 
http://www.kompas.com/.

25/05/2010.

Rasyaf, M. 1984. Memelihara Burung Puyuh. Kanisius, Yogyakarta.

Subekti, E. 2009. Pengaruh penambahan vitamin $\mathrm{C}$ pada pakan non komersial terhadap efisiensi pakan puyuh petelur. JurnalIlmu Ilmu Peternakan. 8(1) : 1-8.

Tillman, A. D., H. Hartadi, S. Reksohadiproji, S. Prawirokusumo dan S. Lebdosutjoko. 1991. Ilmu Makanan Ternak Dasar. Gadjah Mada University Press, Yogyakarta.

Triyanto. 2007. Performa Produksi Burung Puyuh (Coturnix coturnix japonica) Periode Produksi Umur 6-13 Minggu pada Lama Pencahayaan yang Berbeda. Fakultas Peternakan Institut Pertanian Bogor, Bogor. (Skripsi).

Wahju, J. 2004. Ilmu Nutrisi Unggas. Cetakan V. Gadjah Mada University Press, Yogyakarta.

Yuliansyah, M. F., W. Ekodan H. D Irfan. 2015. Pengaruhpenambahan sari belimbinwuluh (Averrhoabilimbi L.) sebagai acidifier dalampakanterhadapkualitas internal telurayampetelur.

JurnalNutrisiTernak. 1(1): 19-26.

Zahra, A. A., D. Sunarti, E. Suprijatna. 2012. Pengaruh pemberian pakan bebas pilih (Free choice feeding) terhadap performans produksi telur burung puyuh (Coturnix coturnix japonica). J. Anim Agri. 1 (1) : 111. 